\title{
Spaces of exception: southern multilingualisms as resource and risk
}

\author{
Kathleen Heugh, Christopher Stroud and Angela Scarino
}

\begin{abstract}
In this paper we draw attention to people who journey from one temporal and spatial setting towards another in the 'South', who aspire to a reconfigured sense of belonging, prosperity and wellbeing, and their multilinguality and multilingualisms. Through three vignettes of journeys we illustrate how in changing of place that linguistic diversities are encountered and mediated. During moments of North-South and South-South entanglement and exception we argue that multilingualisms re-ecologise along horizontal axes of conviviality, and / or reindex along vertical axes of exclusion. We suggest that 'rooting' and 'rerouting' multilingualisms are not only multidimensional, but they are also multifaceted as people who choose or are obliged to experience displacement, undertake journeys of anticipation of replacement into regulated or unregulated situations.

Multilingualisms in the memories, dreams, complex selves, materiality and complicities of coping have yet to receive sufficient attention from linguists. We attempt to capture these aspects and suggest that southern multilingualisms have much to offer and entice northern multilingualisms. We illustrate how closely integrated are multilingual repertoires with mobilities and temporalities of dislocation and change; with loss, nostalgia and the anticipation of new beginnings; and with multi-scaled complicities between individuals as they re-calibrate lives in turbulent and changing circumstances.
\end{abstract}

\section{Introduction}

In this final article of the special issue, Diversities, affinities and diasporas: Implications of southern multilingualisms for policy and planning, ${ }^{1}$ we address the thematic tropes of southern people who experience loss as they undertake a journey from one temporal and spatial setting towards another, and also their aspirations of a renewed or reconfigured sense of belonging, prosperity and wellbeing. As discussed by numerous scholars, the notion of 'south' or 'southern' (Comaroff \& Comaroff, 2012; Connell, 2007; Santos, 2012) is a metaphor that represents a de-colonial stance of resistance to lingering hegemonies of 'northern' coloniality. Papastergiadis (2012), for example, suggests that 'south is a state of mind' rather than a geo-political construct. Through three vignettes of mobile people literally and figuratively moving 'south', we hope to illustrate the plurality of southern multilingualisms. These include (a) how people who journey and change place do not encounter or mediate a singular arrangement of 
linguistic diversity or multilingualism; (b) how multilingualism in one setting is not the same as in another; and (c) that attempts to define multilingualism as a phenomenon are unsatisfactory; the illusiveness of multilingualisms lies in their heterogeneity of phenomena (see also Heugh and Stroud, this volume). We draw on the historical interconnectivities among people who travel, whether from east to west, or from south to north, or back again - what Kerfoot and Hyltenstam (2017) refer to as North-South and South-South entanglement. In these entanglements, we also draw upon or calque the notion of a 'state of exception' (Agamben, 2005) to suggest that there are historical moments of exception when, as a result of human mobility, multilingualisms reecologise along horizontal axes of conviviality, and/or re-index along vertical axes of exclusion (cf. Heugh, 2017). We also suggest that the disappearing and reappearing, or rerouting and rooting of multilingualisms is not only multidimensional, but also multifaceted. In each of the narratives below, during a moment or 'state of exception' (cf. Agamben, 2005), people who choose or are obliged to experience dis-placement, undertake journeys of anticipation of re-placement into spaces of exception, each of which has unique characteristics. In Vignette 1 , mobile people re-place themselves in a space of transparent regulation. In Vignette 2, seafaring travellers find themselves caught in murky spaces of regulated and unregulated entanglements. In Vignette 3, a displaced person flees from one space of disorder only to find himself in another. There is a temporality in these spaces which is characterised by the ebbs and flows in which the bonds among people unfurl, weaken and bring vulnerabilities - but if things go well (as we shall see in Vignette 1), they may also cohere and strengthen in new formations of affinity, sociality and collectivity. In each of the vignettes we choose a particular facet through which to explore a journey of North-South and South-South entanglement from one context of diversity into another, juxtaposed with a human desire for bonds of (re-)affiliation. The first of these journeys begins just before and immediately after World War II - a 'state of exception' - and leads through a regulated space of transparency from a town in Southern Italy to South Australia and towards new multilingualisms, prosperity and 'buen vivir' (Walsh, 2010). The second journey, occurs immediately after a significant change of political order, and during a 'state of exception' in the mid-1990s, one of a hopeful imaginary for a peaceful and convivial future South Africa. This journey turns out to be one of deception in which seafaring travellers are inveigled into to ambiguous and complicit entanglements with opportunistic tricksters. These occur at the intersection of regulated and unregulated spaces of exception in the underbelly of the southern-most port in Africa. The third journey, subsequent to civil conflict in the Democratic Republic of Congo, is one of a state of exceptional displacement. It is one of ongoing loss, loneliness and vulnerability in affiliations of an asylum seeker's journey from Central to Southern Africa after the appalling consequences of civil war. It is a narrative with misleading twists, turns and rescriptings in order to eke out a survival of impermanence and poverty. What each of these vignettes shows is how the lives and fortunes of people are tied to manifestations and resources of multilingualism that differ. In the first two pieces, multilingualism features in people's resourcefulness, with various degrees of 
indexed legitimacy and either conviviality or trickery. In the last vignette, a particular exercise of multilingualism serves as one among many other 'technologies' to drown the multivocality of an asylum seeker/ undocumented migrant. Each of these facets, we suggest, is indicative of centuries, perhaps millennia, of experiences that weave tapestries of complex multilingualisms in southern memory.

\section{Vignette 1: diversities among post-World War II Italian migrants to South Australia / Angela Scarino \\ Introduction}

This vignette presents an example of one community of Italians among many whose lives are interwoven with the Italian diaspora communities of South Australia. Although the Italian community has been and still is (at the most recent census) one of the largest migrant communities in South Australia, it is nevertheless a minority group in the state. Being a minority in any country always brings the vulnerabilities of being seen by the dominant group to belong elsewhere. ${ }^{2}$ The success of many Italian people in having now entered numerous spheres of professional and social life, and the way in which the Italian culture has become enmeshed in the South Australian reality and brought a different valuing of Italy, Italian people and Italian-ness, to some extent masks dimensions of the vulnerability. Nevertheless, traces of the complex history of post-World War II migration experiences of families remain across the generations.

The account in this vignette is based on a research and community-driven project that captured a phase in the (now) almost 100 years of history of the migration experience of people from San Giorgio La Molara (a small town in the province of Benevento, in southern Italy), who settled and live in diaspora in Adelaide (Mercurio \& Scarino, 2004). It focuses on those who made the decision to leave, recognising that their decision has impacted on their children across subsequent generations. It captures the cycles of leaving, living, returning, melding, (dis)connecting and disappearing. The first phase included a group of five men who left San Giorgio La Molara in 1927 and went to South Australia to work as labourers. They were followed in the late 1940 os and 1950 os by thousands who left for various reasons - wanting a new beginning, or seeking change or independence, or wanting greater prosperity and success for their children. They came with their children, who would remember little of their birthplace and gradually assumed a life in English. Some maintained an affiliation with the sangiorgese dialect/ standard Italian and others distanced themselves from it, depending on what the dialect and Italian language symbolised for them.

The longue durée of the migration story captured through the project afforded the community and ourselves as authors (my colleague Antonio Mercurio and myself) an opportunity to reflect on living in diaspora, in the context of ongoing change. This change has taken place and continues, both in the 'homeland' - now a country of immigration), and in South Australia - the receiving country, post-World War 
contested immigration policy. These 'neo-migranti' are a part of the new global diaspora whose myriad communication and travel channels and legal statuses affect their conditions of living, but in ways that are markedly different from the earlier Italian migrants and the sangiorgesi of this vignette. The accounts of both the success in transformation and at the same time the vulnerabilities of the experience of the sangiorgesi invite a (re)consideration of living in diaspora in South Australia and the making of history.

\section{Living in diaspora in South Australia}

The narratives capture, through in-depth interviews during the course of the project, diverse facets of the experience - the decision to leave (with fear, apprehension, loneliness, hope, determination); living (in the initial years with a focus on survival, work, building a home, education of children and learning the English language); returning (to San Giorgio La Molara/Italy to understand themselves, to reconnect with family, to stay or to sell or to decide to return no more); reflecting (on life, work, friends, children, passing) and connecting (with Italians, the Australian community and change).

Living in diaspora was a common story, experienced differently by individuals. One story, for example, was told by the daughter of one of the first migrants who had left San Giorgio La Molara in 1927. On arrival he had been unsuccessful in finding work in Adelaide because of the Depression, and ended up instead in remote Halls Creek (in northern Western Australia). Intertwined within the narrative of her father's story was her own emotional encounter for the first time with Australian Aboriginal people and her return with her own children to Halls Creek 50 years later to recall and recount an extraordinary story. Another was the story of a young man who fought as a member of the Australian Army in New Guinea. He recounted his visits, every Anzac Day, to the family of an Australian soldier whose death in combat he had witnessed. Yet another told the story of discrimination when her requests for help as a pregnant woman were denied. Many told of the cycle of ordinary but significant events (births, christenings, weddings, going to school/ being educated and funerals) or their experiences of war, work and, above all, difficulties with gaining the English language. The diverse accounts offer a picture of how they reacted, adapted, endured and ultimately developed understanding.

Their stories affected them, their beliefs and every facet of their lives and practices and identities. They are significant not only for their social, cultural and historical interest but specifically because these experiences in historical time represent simultaneously the way the tellers reconfigured them for themselves and how they influenced subsequent generations of their families.

\section{Process of history making}

Through in-depth interviews of some 30 participants (both individual and group), we elicited narratives drawn from the 'mental archives' (Gardner, 2003) of individual sangiorgesi. They 
capture the migration experience as socially transformative, without silencing experiences of discrimination, neglect and settlement difficulties. The value of narrative resides in that it offers a memorialisation and account of the past, which is then retold in the present with the benefit of reconfiguring the experience. As Ricoeur (1991) states in relation to time and the power of narrative:

We could say that there are two sorts of time in every story told: on the one hand a discrete succession that is open and thematically indefinite, a series of incidents ...; on the other hand the story told presents another temporal aspect characterized by the integration, culmination and closure owing to which the story receives a particular configuration. In this sense, composing a story is, from the temporal point of view, drawing a configuration out of succession. And in the reconfiguring we come to understand the story as lived as well as the meaning and emotion that it evokes at the time of the telling. (p. 22)

It is well understood that the force of memory will manifest contradictions and discontinuities (Passerini, 1988), along with expressive insights. There may well be selectivity in memory, choices about what is included and excluded, but the narrative's value remains in putting temporal experience in order. The goal for us as researchers and authors, however, was to seek to capture the complex reality and diversity of life in diaspora of the sangiorgesi.

The narratives incorporated a variety of languages - the sangiorgese dialect, Australo-Italian, Italian and English - in a variety of combinations, which we captured through recordings and sought to represent in written form. The languages were not bounded, but mixed naturally and authentically in the communicative world of the migrants.

As authors, we problematised continuously throughout the life of the socio-historical project, the question of the nature of the history that we were presenting and how best to represent the experiences of individuals within a larger collective and the natural and necessary movement between past, present and future. The history was told not as chronology, but rather as recollections, rewritten narratives (in poetic form) and through a sustained visual narrative.

This took the form of a photographic narrative, comprising 350 private photographs taken from albums of members of the sangiorgese community, that captures moments in the everyday lives of the sangiorgesi living in diaspora. Photographs were featured on every page to ensure maximum participation in the project and to allow at least some access for those who were unable to read in either English or Italian.

We chose to write the history using the first person plural form as a way of rendering the personal narratives of individuals and the collective narratives of a particular and diverse community of people - the sangiorgesi - living in diaspora within a wider community of 
diverse Australians. We also did not wish to conceal our understanding that our own interpretations and narratives were also enmeshed in the history we were telling.

In rendering the history we were mindful of diverse readers, recognising that not all readers would be able to access the diverse languages of the narratives. For this reason, the extensive extracts quoted from the participants were fully transcribed, respecting their spoken language, including a rendering of the spoken dialect in written form as faithfully as possible. The main text was also written in both English and Italian. The extracts quoted from the participants contain all four languages/ varieties: sangiorgese dialect, Italian, English, Australo-Italian. Where the quotation was in sangiorgese dialect or Italian, it was translated into English, as in the example below. This example text (Mercurio \& Scarino, 2004, p. 62) describes the way in which Mr Fox aided Donato De Ionno to 'disappear' on the day when the authorities would come to arrest the Italians in order to detain them during the war.

\begin{tabular}{|c|c|c|}
\hline \multirow[t]{4}{*}{1} & Questo Fox & This Mr Fox \\
\hline & $\mathrm{Ci}$ è detto a mio padre & Said to my father \\
\hline & 'Don,' ci è detto & 'Don,' he said \\
\hline & ‘Mercoledì & Wednesday \\
\hline \multirow[t]{5}{*}{5} & Tu va via' & You go away from here' \\
\hline & Ci ha fatto capire & He made him understand \\
\hline & ‘Qua & 'From here \\
\hline & Sparisci! & Disappear!' \\
\hline & Mio padre s'ha preoccupato 'no poco & My father was a bit disappointed \\
\hline \multirow[t]{5}{*}{10} & Mi diceva lui & He would say to me \\
\hline & Diceva & He would say \\
\hline & 'Che succede?' & 'What's going on?' \\
\hline & No, no, no, no & 'No, no, no, no \\
\hline & Tu devi and à via, & You've got to leave \\
\hline \multirow[t]{3}{*}{15} & Okay? & Okay?' \\
\hline & $\begin{array}{l}\text { E allora quel giorno che lui, mio padre l'ha } \\
\text { mandate via }\end{array}$ & $\begin{array}{l}\text { And so, that day when he sent my father } \\
\text { away }\end{array}$ \\
\hline & L̀̀ so arrivate le autorità & The authorities came \\
\hline \multirow[t]{6}{*}{20} & The police from Adelaide & The police from Adelaide \\
\hline & The Commonwealth Police, or whatever & The Commonwealth Police, or whatever \\
\hline & You know? & You know? \\
\hline & Interview a lot of people there & Interview a lot of people there \\
\hline & Some se l'hanno take with them & Some, they took away with them \\
\hline & You know? & You know? \\
\hline \multirow[t]{2}{*}{25} & L'hanno messo nel campo di concentramento & They put them in the concentration camp \\
\hline & Mio padre è rimasto lì & My father stayed here \\
\hline
\end{tabular}

The use of the sangiorgese dialect cannot be rendered in the English translation, nor can 'errors' made with respect to standard Italian, but the way in which English is meshed in with the other languages (lines 13,18-24), even within the space of a single sentence (line 22) is evident in the transcribed text. In addition to revealing the combination of languages, indicative of the melding that occurs naturally in diasporic communities, language was 
crucial at every point in the lives of the sangiorgesi. Their use of dialect and errors made in the use of standard Italian was understood in some contexts as a marker of a generally low level of education, while in others it was understood as a marker of connection within the sangiorgese community. As researchers, we found that the interviews were enriched when we chose deliberately to speak in the sangiorgese dialect in engaging with the participants. Not speaking English or not having a sufficiently strong command of English meant exclusion and isolation and the need for parents to use their own children or others as translators in order to access necessary services of doctors, teachers and accountants.

It is through language that connection to the 'homeland' and family is maintained across generations; therefore, without language, direct connection is necessarily reduced. The sangiorgese dialect is disappearing as the younger generations in Australia use English almost exclusively, and only some seek to learn standard Italian. In Italy, the younger generations use standard Italian almost exclusively. This loss brings with it a loss of local sangiorgese knowledge and cultural ways of being, both in the homeland and in the Australian diaspora.

Finally, the process of making this history raised a further reflection. This kind of history is often framed by the dominant society as the history of the Italian 'contribution' to the making of South Australia. 3 We would argue instead that, more than being a 'contribution', this is an integral part of the fabric of the history of South Australia

\section{Vignette 2: unexpected multilingualism: illicit and complicit resourcefulness / Kathleen Heugh \\ Introduction}

South Africa was the first country to enshrine the principles of an ambitious policy of multilingualism in the 1996 Constitution, but it was not perhaps as innovative as had been hoped by some of those who, for a decade or more, had been working towards this behind the scenes. Included in the Constitution was provision for 11 official languages and the promotion and development of languages used by minority communities in the country. Constitutional provision had been made for the establishment, also in 1996, of the Pan South African Language Board (PANSALB). Through this body and the advice provided to the Minister for Constitutional Affairs, and Minister for Arts, Culture, Science and Technology, an approach based on 'functional multilingualism' (Heugh, 1996a) in conjunction with an elaborated concept of 'language as a resource' (cf. Ruíz, 1984) was included in the Language Plan Task Group (LANGTAG) (1996) Report. The PANSALB argued for this to be incorporated in an evolving national economic plan, the Reconstruction and Development Programme (cf. Heugh, 1999). Functional multilingualism, together with an elaborated view of language as a resource, was conceptualised as including how people in South Africa make use of the official, minority and community languages for different purposes. Together, in the context of aspirational democracy in post-apartheid South Africa, the terms 
referenced both the constitutional commitment towards linguistic equality through vertical language planning (status, corpus and educational planning) 5 and the horizontal, in-between, porous linguistic resources held and used by multilingual people. Both vertical and horizontal multilingualism have been and continue to be used in the country in different contexts and for different purposes. These include (a) within the apparatus of power, for the formal economy and education; (b) among people who use minority or community languages; and (c) through the multilingual practices of people living and working in urban centres, on the mines, and in market places and informal economic enterprises.

\section{Unexpected resourcefulness}

At the time, government officials were dubious about the relationship between language and the economy or that there might be more to multilingualism than identifying $\mathbf{1 1}$ official languages and giving particular consideration to minority and community languages in South Africa. After several colleagues ${ }^{6}$ challenged me to explore how the notion of language as a resource might contribute to language policy and planning in South Africa, following Ruíz (1984) and the work of Lo Bianco and colleagues in Australia (Lo Bianco, 1987; Stanley, Ingram, \& Chittick, 1990),7 I began to investigate whether there might be economic benefits to the harnessing of multilingual resources. This was made possible through a small research project with seed funding from Wesgro, an agency promoting tourism, trade and investment in Cape Town and the Western Cape Province, which was followed by an additional grant from the national Department of Arts, Culture, Science and Technology (1996-1997). One avenue of investigation was to assess the language needs or services of visitors to the country. Surprisingly, at the time there were no officially collated data of the countries from which visitors to the country came, nor their language needs upon entry or exit at border posts. A small team of three researchers, including two graduate students, Babazile Mahlalela-Thusi and Ludger Shadomsky, undertook fieldwork between 1995 and 1997 to collect evidence of language practices and language needs of visitors at airports and border posts (Mahlalela-Thusi) and at Table Bay Harbour in Cape Town (Heugh); and the rationale for languages selected, taught and used in higher education institutions (Shadomsky) (Heugh, 1996b, 1997). Mahlalela-Thusi's data were particularly instructive in the ways in which informal traders moved back and forth across border posts, the multilingual practices that involved 'cross-border' languages - which coincided with the recent description of multilingualism given by Fardon and Furniss (1994) as 'the lingua franca in Africa'. Shadomsky's data revealed that at Afrikaans-medium universities', postgraduate business students were encouraged to look outwards towards Asia, Africa and South America for future participation in global trade. The Afrikaansmedium University of Stellenbosch, for example, expected MBA students to learn Chinese or Portuguese (useful for trade with Angola, Brazil and Mozambique). In contrast, English-medium universities assumed that major trade and engagement would be with English-dominant countries. The University of the Witwatersrand, for 
example, had recently terminated its offering of Portuguese language courses, even though this university is only a half-day car journey from the border with Mozambique, where Portuguese is the official language. By the early 2000s it had become obvious that it was the international business enterprises run by Afrikaansspeakers that had gained substantial and highly profitable interests in China and Brazil ahead of English-speaking South Africans. 8

\section{Complicit and illicit resourcefulness}

The short narrative that follows relates to multilingual resources in the vicinity of Table Bay Harbour (the Port, an area now known as an upmarket 'Waterfront', which at the time still retained somewhat grubby warehouses and offices of shipping merchants and agents) and the lower end of Cape Town's nearby central business district. Before plucking up sufficient courage to venture into the grimy underworld of the Port area, beginning with a visit to Port officials in Custom's House, a curious advertisement appeared in The Cape Times and The Argus newspapers, 'Japanese language and culture for business men'. Since Japanese was not taught in any of the three universities or any schools in the Western Cape, it seemed intriguing. Eventually, after several phone calls and left messages, someone actually picked up the phone and appeared flummoxed that I wanted an appointment to make enquiries about the teaching of Japanese language and the nature or purpose of their clients' business interests in learning Japanese. The person at the other end of the line was not particularly forthcoming, but eventually agreed to a meeting and provided an address. A colleague at the National Language Project at the time cautioned that it was not a particularly salubrious part of town, but did not elaborate. So I set off and found myself in an area clearly frequented by sex workers and pimps. I knocked on the door of the establishment and found myself astonished to be in a massage parlour with little evidence of Japanese language teaching or learning. Nevertheless, it became clear that one or two of the Japanese speakers in this establishment served as translators and interpreters for shipping agents in the Port, and also that other persons with scarce linguistic resources, including Russian and Chinese, provided similar services. Some days later, the Assistant Port Captain and Senior Pilot provided information about the (in-)efficacy of English as the international language of the maritime community, English being a requirement of the Master Mariner's Certificate, an international qualification for ships' captains. Ships' captains were and are responsible for communicating in English with pilots and tugboat captains about dropping or heaving anchor and boarding vessels and for complicated manoeuvring (positioning) orders related to 'routine shiftings and dockings', as well as for communicating with the shipping agents when arriving or leaving Table Bay Harbour. There were apparently many difficulties with this, including significant human and financial consequences of things going awry owing to the lack of the Port authorities' multilingual proficiencies and/or the lack of international ships' crews' English proficiency (Heugh, 1997). There was something else that offered interesting (although unanticipated) but related evidence of multilingualism as an economic resource. The Port officials confirmed that underworld characters with 
expertise in Chinese (Cantonese, Mandarin and Taiwanese), Korean, Russian and Japanese frequented the offices of ships' agents and chandlers. In addition, at least three known (related) triads controlled parts of the city centre at night and over weekends through protection rackets. What was then considered scarce linguistic expertise in the languages mentioned above was also clearly considered an economic resource. The 'Russian' interpreter, for example, did not tolerate any competition with his linguistic services. The Port officials offered further information. At first this seemed to do with multilingual practices relating to the crews of foreign-owned vessels and the formal and informal economic activities in which they engaged during onshore visits to Cape Town. This information was later cross-checked with and confirmed and amplified by local shop owners and junior immigration and court officials. 9

Crew disembarking after long journeys at sea were in search of large quantities of provisions, such as freshly ground coffee, cigarettes and liquor, which parsimonious ships' agents and chandlers did not provide. Crew members were also in search of sex workers. With considerable resourcefulness, local taxi drivers had developed proficiency in several languages, particularly Chinese, Korean and Japanese, in order to ferry 'big spender' foreign sailors to carefully selected vendors and suppliers of other services. One of the vendors turned out to be a coffee shop owner with whom I was acquainted, who provided additional information about the processes in which sailors procured supplies through taxi drivers. Taxi driver introductions of sailors to vendors resulted in an outrageous inflation of prices with handsome kickbacks for the drivers. The coffee shop owner indicated that the remaining profits had to be handed over to the triad-operated protection racketeers in order to avoid break-ins, theft and damage to goods at night or over the weekends. Thus, an underworld ecology of financial transactions and profiteering, facilitated by resourceful multilingualism, followed circular routes through illicit and complicit means in, around and out of the Port.

As indicated earlier, the taxi drivers also doubled up as pimps for sex workers, who had similarly learned that multilingual proficiencies were of financial benefit. There was more, though. Through various mishaps, foreign sailors mistakenly left behind by their vessels would inevitably be arrested by immigration officials tipped off by taxi drivers. They would be charged for contravening immigration laws, obliged to appear in the Cape Town Magistrates' Court, face deportation orders and handed over to shipping agents with triad connections for repatriation. Under South African law, an accused person is entitled to an interpreter. At the time, there were no official court interpreters for languages used by most international crews. So, although prostitution and pimping were illegal offences in South Africa at the time, sex workers with scarce language expertise were regularly called upon by court officials to serve as interpreters.

In the heady years shortly after a transition from an apartheid to a post-apartheid order in South Africa from 1994 to 2000, high-brow legislation and infrastructure (e.g. the 
PANSALB) were being established to protect and support multilingualism for official purposes in government services. Ironically, few of these had any lasting success, and yet, in the murky underworld around Table Bay Harbour and the night-time activities of foreign triads, pimps and sex workers, a highly-organised informal industry facilitated through resourceful multilingualism was thriving in illicit behaviours that clearly involved complicity with various arms of the law. At the time, there was little public knowledge of the extent of these practices in international crime monitoring, for example:

As a major locus of maritime trade and air traffic between Asia, Europe, and the Western Hemisphere, South Africa is emerging as a significant hub of international criminal activity. The lifting of international trade sanctions with the end of apartheid has made South Africa readily accessible to international criminals whose operations take place within the framework of legitimate commercial business activities. South Africa's modern airports and harbors - including container ports at ... Cape Town ...are attractive to criminals smuggling narcotics and other contraband. (Federation of American Scientists, 2000)

At the time, language policy and planning documents, including in relation to the economy (e.g. Language Plan Task Group, 1996), drew attention to regulated and situated multilingualism rather than unregulated ecologies and informal economies, whether in the underbelly of the country's ports and border posts, or in relation to the complicities of agents who transversed legal boundaries.

\section{Vignette 3: supradiversity: or from roots to routes (multilingualismdeferred, multivocality denied) / Christopher Stroud Introduction}

Global migrations and mobility have led to calls for paradigm shifts in sociolinguistics in order to better understand and celebrate the multiplicity of new (super)diversities and complex entanglements. But migration and mobility are not just processes of entanglement, hybridity, multiplicity and complexity. Shome (2003), referencing Massey (1994; cf. also Witteborn, 2011), remarks that 'mobility in and of itself is neither good nor bad', noting that 'what matters are the material relations of empowerment and disempowerment that are enabled through the production of mobility' (p. 52). The following vignette is one story among many that can be told about mobility as a disempowering dynamic.

The story is about Joshua $\mathrm{K}$, a 30+ Congolese asylum seeker in South Africa. I first met Joshua when I was parking my car at the local supermarket five years ago. He approached me and asked for work. Although I had no work to offer, we have nevertheless met regularly since then for drinks and talks. What follows is a highly selective synopsis of his many tales. 
Joshua was born in the Eastern Congo in the late 1980 s into a Kirega/Lega (Shabundo), Swahili and Congolese-French speaking family living on the rural/peri-urban outskirts of Bukavu. Like many of his neighbours and family, he suffered devastating and frequent attacks on his village by groups of marauding militias, and experienced the torment of human spill from the genocide in Rwanda. When it became time for Joshua to leave the Democratic Republic of Congo (DRC), family networks enabled him to slowly make his way to South Africa. His journey would take him almost one year and involved crossing six borders before he arrived in Cape Town, where a decade later, he is still awaiting the outcome of his asylum application.

Borders are an intense microcosm of global inequalities. For asylum seekers such as Joshua, these inequalities manifest through processes that inscribe and fix the liminality of the border onto the bodies, sensibilities and narratives of the would-be migrant. Shome (2003) notes how 'transnational relations of capital so fix their bodies that they cannot be displaced into another space' (p. 53; cf. Spivak, 1996). This is the case for Joshua, who is an embodied articulation of the borders and who seems destined to forever be betwixt and between. In Joshua's case, cyclical processes of physical concealment; a powerful sense of shame, nostalgia and anticipation; and the slow erasure of his memories and their reauthoring by others, written to other scripts and genres, are the stuff with which mobility disempowers and disengages. Far from a celebratory superdiversity, Joshua's story tells of a supradiverse world - a world comprised of a very particular human shrinkage, and a concomitant reconstruction of his linguistic repertoire.

\section{The journey}

Joshua K's trip from Bukavu to Cape Town took one year and involved a series of physical concealments, narrative erasures and identity rewrites. On the boat crossing from Bukavu to the Zambian town of Mpulungo, Zambia, the length of Lake Tanganyika, Joshua was concealed in the oily hold of the boat for three days. In Lusaka, where he remained for a number of months, he was forced to stay hidden in a safe-house during daylight hours in order to avoid being arrested by Zambian police looking for illegal immigrants to deport. (He was only able to visit the shebeens (beer parlours) from midnight onwards.) A third erasure, although this time more biographical than bodily, took place at the busy Beit Bridge border between Zimbabwe and South Africa. On arrival at Beit Bridge, he was sorted into a Congolese arrivals' queue (separate from the Somali and Pakistani queues) while the barest and flimsiest of his personal details were duly recorded by the South African authorities. Joshua was given a case number, admitted into South Africa and allowed six months to settle his asylum status, a status that so far he has failed to resolve.

Brigitta Busch (2017) notes how multilingual repertoires emerge and become actualised in moments of (intercorporeal) engagement. Joshua's cycles of self-concealment and the reduction of his identity narrative to a case number have over time been accompanied by a gradual silencing of his multilingual repertoire in Kiswahili, French and Kirega - 
the further south he travelled, the fewer spatial and interactional affordances he has found co host and nurture these languages.

\section{Transnational visceralities}

'Home' is where personal and social meaning is grounded, and where we establish nurturing and caring relationships with others (Papastergiadis, 2006). Joshua left his home behind in the DRC. Over time, his asylum journey has become a struggle for personal survival that has had the effect of hollowing out his connect to family and eroding his self-respect; he turns painfully despondent at what he perceives to be a lack of agency and autonomy. 'Shame' as a component of Joshua's re-authored asylum self has been compounded by the death of three close family members within the past two years: one sister died of malaria, another was killed by a (stray?) police bullet and his mother died of type-2 diabetes because she couldn't afford medication. On each occasion, Joshua has been unable to attend or contribute to their funerals in the way expected of an oldest son. He has had to hand over his responsibility to other, more distant family members. The humiliation Joshua has experienced in failing his family duties compounds a further erasure of an adequate sense of self.

Besides shame (and the despondency/despair associated with his helplessness in his family's times of need), two other strong emotions make up Joshua's transnational visceral body, namely, nostalgia and anticipation. Both of these emotions are responses to not being there, of being elsewhere, removed from or not yet having reached a desired state or experience. Viscerality is one way in which we structure and organise our world, and in Joshua's case, his sentiments would seem to re-organise his languages in a different chronotopical frame than English.

\section{Turbulent stillness}

Travelling is not just about movement, but also moments of waiting (Juffermans \& Tavares, 2017), often chronic waiting (Martin, 2011) filled with bouts of uncertainty and despair at being left behind, of not moving forward, of being put on hold. Martin (2011) refers to this as 'turbulent stillness'. Joshua has been waiting still now for a decade. The betwixt and between-ess of his embodied bordering makes itself felt in lost opportunities for work and income (no work permit), and in a generally perilous life situation.

In Cape Town, Joshua tries desperately to extricate himself from a dangerous vortex of vulnerability (material, economic, financial, medical) that is drowning his dignity. He lives in a rundown flat with 9-10 other migrants, men and women (as well as children) of different African backgrounds. The slum landlord charges three thousand Rands (approximately USD 230) per person per month sharing this rat-infested house, ('rats as large as poodles'). Joshua shares one bed with two other Congolese men. There is a narrow kitchen cupboard that has been converted to shower-cum-toilet for nine people and two children. During the recent 2018 water crisis in Cape Town with severe restrictions of a maximum of 350 litres a 
day per household, households such as these would easily exceed the limit and invariably the city would close off their water. Joshua is waiting (Juffermans \& Tavaresavares, 2017).

Bad locks on bedroom doors, and many people stricken by poverty in rundown neighbourhoods looking for a means to survive, has meant that Joshua has repeatedly been the victim of violent robbery and theft. Not long ago, his room was broken into and items of his clothing were stolen, as well as letters, photos and other memorabilia that he had brought with him on his journey as anchorage in another life. ${ }^{10}$ The loss of material dimensions of his repertoire, such as photos out of which stories emerge and that serve as linguistic archives, is a further disconnect from the past, and the languages in which this past was authored.

\section{Complicities}

Referring to undocumented migrants, Martin (2011) has noted with others how the designation of illegality forced onto these people creates an extended network of dependency on actual forms of illegality' (p. 194). To get ahead in the queue at Home Affairs for permit renewal (and not have to come back the following day), Joshua would borrow a toddler from a good friend and stand with him in the line, or he would don a neck brace typically suggesting or simulating a broken neck from a motor bike accident. A sympathetic guard would then wave him to the front. These complicities, or minor illegalities, reach into the very core of the system, as when he on one occasion received and appealed a 'Must Go' (the official deportation order). Joshua asked for an interpreter, as is his right. The Home Affairs officers combed the floors for an interpreter and finally find one. However, the interpreter was Malawian and able to interpret only between Chichewa and English. Having only English in common, the interpreter resorted to 'translating' between Joshua's English and the English of the isiXhosa-speaking Home Affairs official. Despite, or perhaps because of this, Joshua got an extension on his permit to stay. These examples are typical of the many types of complicity that contribute to maintaining the asylum seeker in a parallel space of exception, where in order to get things done and business accomplished, extra-legal tactics become the order of the day. Vulnerability has its own generative logic of erasure of other languages in favour of English.

\section{Joshua's stories}

The Nigerian author Chimamanda Ngozi Adichie (2009) in 'The danger of a single story' tells how we are the stories we tell about ourselves. She warns against looking for just one story and urges us to explore all of them - happy stories as well as sad - in their diversity. Joshua has many stories about his travels, however, in Joshua's case, the many stories of war, desecration, hope of a new future, sadness at the present are overlaid - replaced - by one story only. It is his 'official', deposited and told and retold to Home Affairs, comprising a short autobiographical piece that Joshua asked me to translate from a handwritten French text into English for one of his asylum interviews. It tells of a family partially destroyed, and displaced by war in Eastern Congo, and is precise in the detail of the miseries it recounts. 
This is Joshua's story as told to immigration officials, and it serves to situate his asylum travels against the backdrop of the Congolese-Rwandan warscapes.

This story is the official (re)authored version. It recounts a series of events that accord with the official genre of escape and salvation. This is a genre that finds its rationale in an understanding of mobility/migration as a disequilibrium from the normal state of nation state-bordered sedentary living, and sees the mobility of the undocumented asylum seeker as a forced disruption from a belonging, brought about through circumstances beyond their control. It is a genre that cannot easily accommodate a more complex idea of mobility as a multi-scaled condition of transnational, global modernity, and it rules out multivocality and complexity in favour of a narrative format that seeks less to reveal any 'truths' about the asylum seeker, but to conceal the contradictions and bury any ambiguities. It denies audibility to the many voices and their entanglements by disconnecting from individual pasts in the interest of uniformity (cf. Blommaert, 2009 for another, but compatible, approach to asylum seeker narratives). The genre has a narrative form that is robustly monolingual in the sense that David Gramling writes about in his book, The invention of monolingualism (2016); that is, the idea that everything is sayable in any one language. Although Joshua is the author and animator (as well as protagonist, victim), he is not the Goffmanian principal of this text. The way in which Joshua is interpellated in this narrative is reminiscent of the colonial tropes that subdued and distorted the voices of the native/subaltern.

\section{A Fanonian framing}

Joshua's travels across borders, physical concealment and narrative erasure, the visceralities of distance and disappointment, the descent into abject vulnerability, the forced complicities in illegalities and the reauthoring and revoicing of his asylum narrative is almost a Fanonian practical. Fanon's (1967) metatheory of failure as the generative process in the construction of disempowered (black) subjectivities - those who inhabit the zone of non-being - offer a good fit to Joshua's story. For Fanon, subjectification of black - read disempowered individuals - is a complex, co-constructed semiotic of difference under conditions of denial and the absence of intersubjective mutuality. To paraphrase Fanon, Joshua is symbolic and semiotic of global inequality made materiality and flesh. Fanon highlights the 'fundamental importance of language' in the violent formation of racialised colonial subjectivities. In Joshua, we see how the erasure and restructuring of his multilingual repertoire is a necessary part and outcome of the (affective, material and bodily) invisibilisation (Kerfoot, 2017) and renarrativisation of his history.

\section{Multilingualism}

Multilingualism as we commonly think of it gestures towards a promise of rooting, of being able to establish footing in multiple soils - of settling, if not in one community only, then in many unbounded and interlocking and entangled, porous, even technologically mediated, communities. We could call this 'residential multilingualism'. This is a multilingualism that maps multivocalities onto one dominant singularity of voice - irrespective of the language in 
which this voice finds expression. In Joshua's case, it is a multilingualism that operates by delinking from the stories as he could tell them, rupturing entanglements of historical happenings and affects, and reinscribing his narrative into another mode. In the process erasing unsettling difference, this is a multilingualism of the abyssal, a semiotics of writing/reading the other through how s/he is perceived by the self. It creates a supradiverse world inhabited by an endless multiplicity of shells of selfhood and hollow narratives.

An alternative, nonresidential multilingualism would embrace the Fardon and Furniss (1994) concept of 'multilingualism as the lingua franca of Africa'. It would be an idea of multilingualism that highlights and celebrates the novelty, unpredictability and multivocality of encounters across difference; it would provoke thinking on multilingualism as that which facilitates meetings, exchanges and engagements with different others, rather than as a tool of semiotic imposition of an alien and unwanted self. Such a view of multilingualism reflects a view of mobility as something that 'creates its own momentum, pathways and boundaries' (Papastergiadis, 2010, p. 356). It is thus a multilingualism of routes and rerouting, rather than of roots - an unrooted multilingualism (cf. Phipps, 2013 on 'unmoored multilingualism').

A multilingualism of routing differs from the idea of intercultural communication, which is a paradigm for bridging difference and creating common ground. Intercultural communication rests on the same suppositions as 'residential multilingualism', that is, an idea of diversity and multivocality coupled with the assumption that it is possible/desirable to go beyond difference, so as to be rid of uncertainty and surprise (cf. Phipps, 2014). This paradigm may be a non sequitur if the other to which selves should relate has already been invisibilised, erased in the production of supradiversity.

\section{Conclusion}

There is already circulating in southern contexts ample literature and debate in which the interconnectivities of North and South are evident in neo- and even postcolonial views of linguistic diversity or multilingualism. Mapped into the apparatus of the colonial mirror of the nation state, this literature frequently casts multilingualism as simultaneously a 'normal' reality in everyday spaces, and yet also somehow 'aberrant'. The sense of abberance appears in neocolonial discourses in southern contexts, accompanied by a focus of attention towards 'problems' that appear to threaten the chimera of unity and identity that underpin adhesive notions of the faux nation state. It also occurs when rather different debates and discussions of multilingualism that have circulated in southern contexts for a century or more do not coincide with what have become dominant views in the northern academy. Here we refer to a positioning of multilingualism, for example, as a set of parallel monolingualisms (e.g. Blackledge \& Creese, 2010; Heller, 2007). Such a view formulated in northern contexts, if assumed to apply to perceptions of multilingualism in Africa or India, would be symptomatic of coloniality and hegemony. It bears little resemblance to the reality of multilingual societies as captured in the notion of "multilingualism is the lingua franca of 
Africa' (Fardon \& Furniss, 1994). When multilingualism is acknowledged, it is often in the sense of what Christopher Stroud in Vignette 3 calls 'rooted multilingualism', rather than a 'routed multilingualism' of contact and encounter. An understanding of routed multilingualism and the linguistic agency of multilingual citizens (Stroud, 2018) at the local or micro-level (Liddicoat \& Baldauf, 2008) have significance for language planning alongside 'public discourse, debate, argument, persuasion, and ... the actual performative and communicative practices of citizens' (Lo Bianco, 2017, p. 40).

There is an increasing body of literature that draws attention to heterogeneity (Busch, 2017) and a reawakening of northern attention towards multilingualism (e.g. Franceschini, 2013; May, 2013; Sachdev, Giles, \& Pauwels, 2012; Singleton, Fishman, Aronin, \& Laoire, 2013). Yet, even in discussions of linguistic diversity and heterogeneity, multilingualism is usually framed as if it were a phenomenon. What authors in this special issue have attempted to do is to demonstrate that temporality, space, moments of exception and the weaving of tapestries of southern phenomena of multilingualisms are not easily pinned down. They are not easily defined in literature that is disconnected from a long history and the very interconnectivities of North with South and of South with South (Comaroff \& Comaroff, 2012; Connell, 2014; Kusch, 1970/2010; Mignolo, 2010; Santos, 2012), or the ways in which multilingual citizens reconfigure their identities (Lim, Stroud, \& Wee, 2018; Stroud, 2018; Williams \& Stroud, 2013).

The place of multilingualisms in the fabric of memories, dreams, complex selves, materiality and the rough-and-tumble of getting by - the complicities of coping, often in spaces of exception - have yet to receive the attention they merit from linguists. In the vignettes included in this final article we have tried, to some extent, to capture these aspects of multilingualism, and we believe that southern multilingualisms have much to offer and entice northern multilingualisms in this regard. We illustrate how closely integrated multilingual repertoires are with mobilities and temporalities of dislocation and change; with the pain of leaving, the nostalgia of memory and the anticipation of new beginnings; and with the multiscaled complicities among individuals as they re-calibrate lives in times of turbulent and changing circumstances.

Papastergiadis (2012) remarks on how 'the south is a highly ambivalent concept', suggesting that the 'south is not a place in the world; it is a space where people meet to imagine the possibility of other ways of being in the world' (p. 26). In our related disciplines of applied and sociolinguistics, it is a move away from the grain of a colonial past - away from the bifurcations and splinterings that have cleaved a gap between southern and northern experiences of multilingualisms over the past decade. It is what Papastergiadis refers to as a third space in which there is 'rapprochement'.

This is precisely the spirit we have wanted to capture with this special issue - an invitation to an imagining of other ways of being multilingual in the world. As southern travellers who 
ourselves follow routes of 'orbiting diasporas' (cf. Simpson \& Wigglesworth, 2018), we anticipate a consciousness of multilingualisms that permeates conversations of linguistic heterogeneity as phenomena of interconnectivities

\section{Notes}

1. As authors of this paper and as editors of the special issue, we should like to acknowledge our appreciation of Kate Loechel's curation of and contributions to the editing processes. We should also like to express our appreciation of Tony Liddicoat's generous patience and forbearance.

2. This study predates an increasing body of recent research relating to migration (e.g. that included in Guveli et al., 2016), and it differs in emphasis. The gaze is not so much towards vulnerabilities of migrant people, but rather how, a southern Italian community in the diaspora has melded into and shaped the very fabric of South Australia.

3. The most contemporary manifestation of this contribution can be seen in the Australian Council of Learned Academies' report: Australia's diaspora: Realising the potential for building transnational business networks with Asia (Rizvi, Louie, \& Evans, 2016). In this report an argument is made for the recognition of diasporas as a source of economic 'innovation' and 'enterprise' that is currently underutilised. Although this report is focused on Chinese and Indian diaspora, the notion of contribution in this context may well be extended to other communities living in diaspora.

4. Angela Scarino wishes wish to acknowledge the work of Dr Antonio Mercurio as a fellow researcher on the project in this vignette.

5. Vertical language policy and planning under apartheid had been used to segregate people along ethnolinguistic lines of inequality and thus it was assumed that 'corrective' or democratic principles of equality and inclusion would require specific interventions to equalise the status of major African languages, together with the protecting and promoting other communitylanguages.

6. Heugh and Alexander, a prominent anti-apartheid political activist and historian who developed an interest in post-apartheid language policy, worked together from 1988 to 2004 on language policy (including language education policy), in the National Language Project, the Project for the Study of Alternative Education in South Africa at the University of Cape Town, the Language Plan Task Group of South Africa, and the statutory body, the PANSALB. Colleagues Gerda de Klerk, Amanda Siegrühn and Peter Plüddemann encouraged exploring the relationship between language and the economy. 7. The circulation of the ideas of Richard Ruíz a scholar from Arizona immersed in Chicana/o decolonial thinking, along with Lo Bianco and colleagues in Australia and post-apartheid language policy activists in South Africa, is an early example of SouthSouth collaboration in the field of postcolonial and possibly decolonial language policy and planning.

8. For example, Cape Town publishing giant, Naspers, became the largest stakeholder in Chinese social network provider Tencent between 2000 and 2017. It has recently sold $2 \%$ of its 33\% stake for US $\$ 9.8$ billion (Deng \& Chen, 2018). 
9. Data were collected in May-July 1996. Although some of the information that follows was included in official reports for the Department of Arts, Culture, Science and Technology (cf. Heugh, 1996a, 1996b), hinted at in the Language Plan Task Group (LANGTAG) Report (1996), and provided in some detail in several public forums/conferences over the next two years (e.g. Heugh, 1997), this did not fit the anticipated framing of multilingualism within 'officially' sanctioned or regulated policy and planning.

10. Joshua recovered some clothing literally off the back of a young boy he passed by on the street a day or two later. The boy claimed to have bought the items at a local flea market. The photos and letters were never recovered. 


\section{References}

Adichie, C. N. (2009). The danger of a single story, TEDTalks video from TEDGlobal 2009. Retrieved from https://www.youtube.com/watch?v=D9Ihs241zeg

Agamben, G. (2005). State of exception. Chicago: University of Chicago Press.

Blackledge, A., \& Creese, A. (2010). Multilingualism: A critical perspective. London: Continuum. Blommaert, J. (2009). Language, asylum and the national order. Current Anthropology, 5o(4), 415-441. doi:10.1086/600131

Busch, B. (2017). Expanding the notion of the linguistic repertoire: On the concept of Spracherleben -the lived experience of language. Applied Linguistics, 38(3), 340-358.

Comaroff, J., \& Comaroff, J. L. (2012). Theory from the south: Or, how Euro-America is evolving toward Africa. Anthropological Forum, 22(2), 113-131.

Connell, R. (2007). Southern theory: The global dynamics of knowledge in social science. Cambridge: Polity Press.

Connell, R. (2014). Using southern theory: Decolonizing social thought in theory, research and application. Planning Theory, 13, 210-223.

Deng, I., \& Chen, C. (2018, March 23). Naspers' stake in in Tencent ballooned 5,600 times in 17 years. Now it's time to take a little profit. South China Morning Post. Retrieved from https:// www.scmp.com/tech/china-tech/article/2138683/naspers-staketencent-ballooned-5600-times- 17-years-now-its-time

Fanon, F. (1967). Black skin, white masks. New York: Grove Press.

Fardon, R., \& Furniss, G. (1994). African languages, development and the state. London: Routledge. Federation of American Scientists. (2000). International crime threat assessment (Chapter 3). Retrieved from https://fas.org/irp/threat/pub45270chap3.html\#r2o

Franceschini, R. (2013). History of multilingualism. In The encyclopedia of applied linguistics. Blackwell. doi:10.1002/9781405198431.wbealo511

Gardner, P. (2003). Oral history in education. History of Education, 32(2), 175-188.

Gramling, D. (2016). The invention of monolingualism. New York: Bloomsbury.

Guveli, A., Ganzeboom, H., Platt, L., Nauck, B., Baykara-Krumme, H., Eroglu, S., ... Eroğlu, Ş. (2016). Intergenerational consequences of migration: Socio-economic, family and cultural patterns of stability and change in Turkey and Europe. Basingstoke: Palgrave Macmillan.

Heller, M. (2007). Bilingualism as ideology and practice. In Bilingualism: A social approach (pp. 1-22). Houndmills, Basingstoke: Palgrave Macmillan.

Heugh, K. (1996a). A plan to operationalise language as an economic resource. For the Language Plan Task Group (LANGTAG) Sub-committee on Language as an Economic Resource. Pretoria: Department of Arts, Culture, Science and Technology.

Heugh, K. (1996b). Why is the water so muddied? The economics of language. Language Planning Report No. 5(2). Pretoria: Department of Arts, Culture, Science and Technology.

Heugh, K. (1997). A pilot study into the relationship between language and the economy of the Western Cape. For Wesgro, the Western Cape Investment and Trade Promotion 
Agency. Cape Town: Project for the Study of Alternative Education in South Africa, University of Cape Town.

Heugh, K. (1999). Languages, development and reconstructing education in South Africa. International Journal of Educational Development, 19, 301-313.

Heugh, K. (2017). Re-placing and re-centring southern multilingualisms. A de-colonial project. In C. Kerfoot \& K. Hyltenstam (Eds.), Entangled discourses. South-North orders of visibility (pp. 209-229). Critical Studies in Multilingualism. New York: Routledge.

Juffermans, K., \& Tavares, B. (2017). South-North trajectories and language repertoires. In C. Kerfoot \& K. Hyltenstam (Eds.), Entangled discourses: South-North orders of visibility (pp. 109-126). Routledge Critical Studies in Multilingualism. New York: Routledge.

Kerfoot, C., \& Hyltenstam, K. (2017). Introduction: entanglement and orders of visibility. In C. Kerfoot \& K. Hyltenstam (Eds.), Entangled discourses: South-North orders of visibility (pp. 1- 16). London: Routledge.

Kerfoot, C., \& Hyltenstam, K. (Eds.). (2017). Entangled discourses: South-North orders of visibility. Routledge Critical Studies in Multilingualism. New York: Routledge.

Kusch, R. (1970/2010). Indigenous and popular thinking in América (J. Price \& M. Lugones, Trans.). Durham, NC: Duke University Press.

Language Plan Task Group (LANGTAG) of the Minister of Arts, Culture, Science and Technology. (1996). Towards a national language plan for South Africa. Final Report of the Language Plan Task Group (LANGTAG). Pretoria: Department of Arts, Culture, Science and Technology.

Liddicoat, A. J., \& Baldauf, R. (2008). Language planning in local contexts: Agents, contexts and interactions. In A. J. Liddicoat \& R. Baldauf (Eds.), Language planning and policy: Language planning in local contexts (pp. 3-17). Clevedon: Multilingual Matters.

Lim, L., Stroud, C., \& Wee, L. (2018). The multilingual citizen. Towards a politics of language for agency and change. Bristol: Multilingual Matters.

Lo Bianco, J. (1987). National policy on languages. Canberra: Government Printer.

Lo Bianco, J. (2017). Revisiting the 'language as resource' orientation for bolstering multilingualism in contemporary urban Europe. In H. Peukert \& I. Gogolin (Eds.), Dynamics of linguistic diversity (pp. 31-48). Hamburg Studies on Linguistic Diversity, No. 6. Amsterdam: John Benjamins.

Martin, C. (2011). Stillness: The politics of uncertainty and the undocumented migrant. In D. Bissell \& G. Fuller (Eds.), Stillness in a mobile world (pp. 192-208). London: Routledge.

Massey, D. (1994). Space, place and gender. Minneapolis: University of Minnesota Press. May, S. (Ed.). (2013). The multilingual turn: Implications for SLA, TESOL, and bilingual education. New York: Routledge.

Mercurio, A., \& Scarino, A. (2004). We left 'E partimmo': Narratives of the Sangiorgesi in Australia, 1927-2003. Adelaide: San Giorgio La Molara Community Centre. 
Mignolo, W. (2010). Introduction. Immigrant consciousness. In R. Kusch (Ed.), (M. Lugones \& J. M. Price, Trans.) Indigenous and popular thinking in América (pp. xiii-lxxiv). Durham: Duke University Press.

Papastergiadis, N. (2006). The invasion complex: The abject other and spaces of violence. Geografiska Annaler: Series B, Human Geography, 88(4), 429-442.

Papastergiadis, N. (2010). Wars of mobility. European Journal of Social Theory, 13(3), 343361.

Papastergiadis, N. (2012). South remembers: What is the South? South as a State of Mind, No. 1, Summer/Fall. Retrieved from http://southasastateofmind.com/southremembers-south-nikos-papastergiadis/

Passerini, L. (1988). Storia e soggettività. Le fonti orali, la memoria. Florence: La Nuova Italia. Phipps, A. (2013). Unmoored: Language, pain, porosity and poisonwood. Critical Multilingualism Studies, 1(2), 96-118.

Phipps, A. (2014). 'They are bombing now': Intercultural dialogue in times of conflict. Language and Intercultural Communication, 14(1), 108-124.

Ricoeur, P. (1991). Life in quest of narrative. In D. Wood (Ed.), On Paul Ricoeur: Narrative and interpretation (pp. 20-33). London: Routledge.

Rizvi, F., Louie, K., \& Evans, J. (2016). Australia's diaspora advantage: Realising the potential for building transnational business networks with Asia. Report for the Australian Council of Learned Academies (ACOLA). Melbourne: ACOLA. Retrieved from www.acola.org.au

Ruíz, R. (1984). Orientations in language planning. NABE Journal, 8(2), 15-34.

Sachdev, I., Giles, H., \& Pauwels, A. (2012). Accommodating multilinguality. In T. K. Bhatia \& W. C. Ritchie (Eds.), The handbook of bilingualism and multilingualism (2nd ed., pp. 391-416). Chichester: Blackwell.

Santos, B. de S. (2012). Public sphere and epistemologies of the south. Africa Development, $37(11), 43-69$.

Shome, R. (2003). Space matters: The power and practice of space. Communication Theory, 13(1), 39-56.

Simpson, J., \& Wigglesworth, G. (2018). Language diversity in Indigenous Australia in the 21st century. Current Issues in Language Planning. doi:10.1080/14664208.2018.1503389

Singleton, D., Fishman, J. A., Aronin, L., \& Laoire, M. Ó. (Eds.). (2013). Current multilingualism: A new linguistic dispensation. Contributions to the Sociology of Language No. 102. Berlin: Walter de Gruyter.

Spivak, G. (1996). Diasporas old and new: Women in the transnational world. Textual Practice, 10 (2), 245-269.

Stanley, J., Ingram, D., \& Chittick, G. (1990). The relationship between international trade and linguistic competence. Report to the Australian Advisory Council on Languages and Multicultural Education, Department of Employment, Education and Training. Canberra: Australian Government Publishing Service. 
Stroud, C. (2001). African mother tongue programs and the politics of language: Linguistic citizenship versus linguistic human rights. Journal of Multilingual and Multicultural Development, 22 (4), 339-355.

Stroud, C. (2018). Linguistic citizenship. In L. Lim, C. Stroud, \& L. Wee (Eds.), The multilingual citizen. Towards a politics of language for agency and change (pp. 1739). Bristol: Multilingual Matters.

Stroud, C., \& Heugh, K. (2004). Linguistic human rights and linguistic citizenship. In D. Patrick \& J. Freeland (Eds.), Language rights and language survival: A sociolinguistic exploration (pp. 191- 218). Manchester: St Jerome.

Walsh, C. (2010). Development as buen vivir: Institutional arrangements and (de) colonial entanglements. Development, 53(1), 15-21.

Williams, Q., \& Stroud, C. (2013). Multilingualism in transformative spaces: Contact and conviviality. Language Policy, 12, 289-311.

Witteborn, S. (2011). Constructing the forced migrant and the politics of space and placemaking. Journal of Communication, 61, 1142-1160. 